\title{
Pisces, Perciformes, Eleotridae, Dormitator maculatus (Bloch, 1792): Distribution extension for Patos-Mirim lagoon system, state of Rio Grande do Sul, Brazil
}

\author{
Matheus Vieira Volcan ${ }^{1 *}$, Morevy Moreira Cheffe ${ }^{2}$, Luis Esteban Krause Lanés ${ }^{1}$ and Marcelo Dias de \\ Mattos Burns ${ }^{3}$ \\ 1 Instituto Pró-Pampa (IPPampa), Laboratório de Ictiologia. Rua Gomes Carneiro 1043. CEP 96010-610. Pelotas, RS, Brazil. \\ 2 Grupo Especial de Estudos e Proteção ao Ambiente Aquático do Rio Grande do Sul (GEEPAA-RS), Setor de Ictiologia, Divisão de Fauna. Rua \\ Tiradentes. CEP 2247. 96010-165. Pelotas, RS, Brazil. \\ 3 Universidade Federal de Rio Grande, Instituto de Oceanografia, Pós-graduação em Oceanografia Biológica, Laboratório de Ictiologia. Campus \\ Carreiros, Caixa Postal 474. CEP 96201-900. Rio Grande, RS, Brazil. \\ * Corresponding author: E-mail: matheusvolcan@hotmail.com
}

\begin{abstract}
We present here the record of Dormitator maculatus (Bloch, 1792) to the Patos-Mirim lagoon system, Rio Grande do Sul, Brazil. This is also the southernmost occurrence in South America, extending species range ca. $150 \mathrm{~km}$ from the previously known localities.
\end{abstract}

Eleotridae comprises about 35 genera and 155 species which inhabit tropical and subtropical areas worldwide (Nelson 2006). This family is characterized by having free pelvic fins (not forming adhesive disk) and a notorious preference for estuaries, with some species that are exclusively to freshwater environments (Nelson 2006).

The Fat Sleeper Dormitator maculatus (Bloch 1792) reaches about $14.5 \mathrm{~cm}$ TL and occurs along the Atlantic slope from North Carolina (USA) to Brazil (Froese and Pauly 2010). This species is found in freshwater and brackish mangrove areas, inhabiting marshes, muddy ponds and channels, with salinity ranging from 0 to 21, (Winemiller and Ponwith 1998; Keith et al. 2000; Nelson 2006). Omnivorous, they feed mainly on plants, sediments, and invertebrates (Winemiller and Ponwith 1998; Keith et al. 2000). The sexual maturity occurs after one year, and during the reproductive season adults change their color, carrying out a complex nuptial parade displaying parental care (guarding the nest) (Keith et al. 2000).

The species, whose type locality is unknown (Kullander 2003), is recorded in south Brazil in the states of Paraná (Abilhoa and Duboc 2004; Queiroz 2006), Santa Catarina (Bertaco 2009), and Rio Grande do Sul (Loebmann and Vieira 2005). Through collection campaigns carried out between 1992 and 2004, in the municipality of Pelotas, southern Rio Grande do Sul, we record for the first time $D$. maculatus for the Patos-Mirim lagoon system.

Between autumn/winter 1992, 34 adults (with $39.3 \mathrm{~mm}$ to $78.2 \mathrm{~mm} \mathrm{SL}$ ) and juveniles (with $9.2 \mathrm{~mm}$ to $14.7 \mathrm{~mm} \mathrm{SL}$ ) specimens of D. maculatus (Figure 1) were recorded in Private Natural Heritage Reserve (PNHR) of Pontal da Barra (31 ${ }^{\circ} 47^{\prime} 08^{\prime \prime}$ S, 52 $2^{\circ} 13^{\prime} 29^{\prime \prime} \mathrm{W}$ ) (Figures 2 and $3)$. In 2004 three specimens were recorded in the lower course of Totó and Salgado-Sujo streams (31 $43^{\prime} 29^{\prime \prime}$ S, $52^{\circ} 11^{\prime} 37^{\prime \prime} \mathrm{W}$ and $31^{\circ} 42^{\prime} 21^{\prime \prime} \mathrm{S}, 52^{\circ} 09^{\prime} 20^{\prime \prime} \mathrm{W}$, respectively), which flow into the Saco do Laranjal (Figures 2 and 3). The specimens were collected using hand nets. Voucher
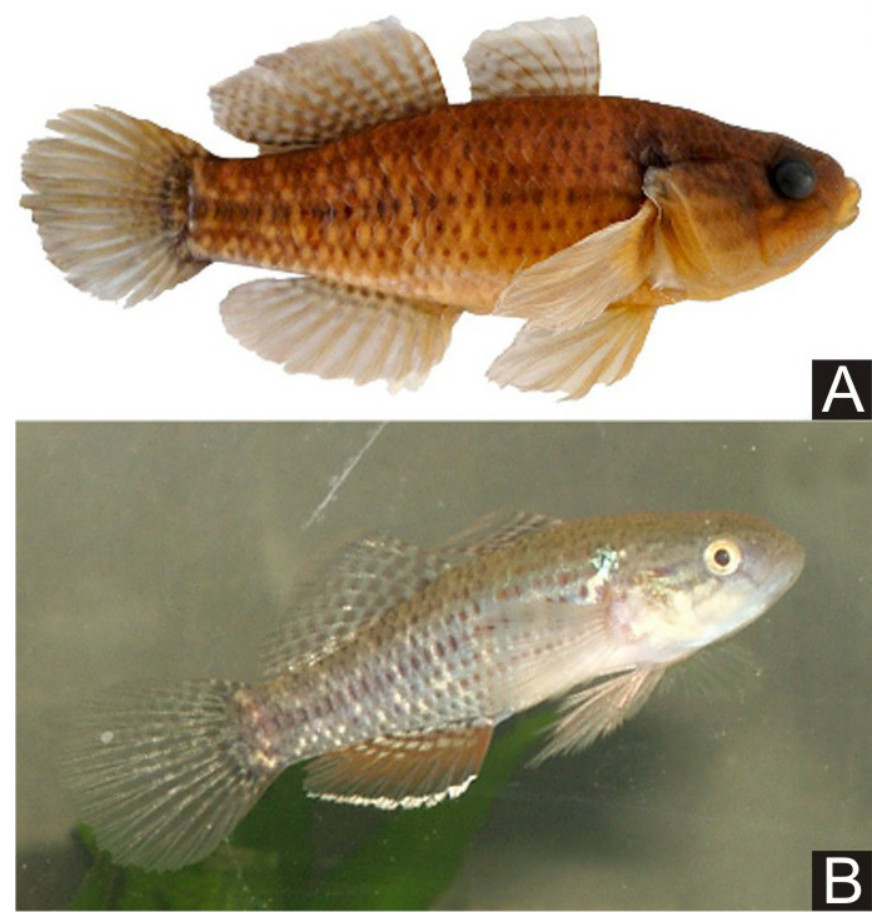

Figure 1. (A) Dormitator maculatus captured in the Pontal da Barra swamps, CIMC 18456, $78.2 \mathrm{~mm}$ SL. (B) Specimen captured in the Totó stream, live aquarium specimen (not preserved). Photos: Matheus Volcan.

specimens were deposited in the following ichthyological collections: Coleção Ictiológica Morevy Cheffe of the Grupo Especial de Estudo e Proteção do Ambiente Aquático do Rio Grande do Sul (CIMC 18042, 5 ex.; CIMC 18088, 11 ex.; CIMC 18191, 5 ex.; CIMC 18456, 1 ex.; CIMC 19004, 4 ex.), and Museu de Ciência da Pontifícia Universidade Católica do Rio Grande do Sul (MCP 17702, 12 ex.). These records represent the southernmost occurrence of these species in South America, extending its distribution $c a .150 \mathrm{~km}$ in a straight line from the previously known locality, at the Parque Nacional da Lagoa do Peixe, state of Rio Grande do Sul (Loebmann and Vieira 2005). 


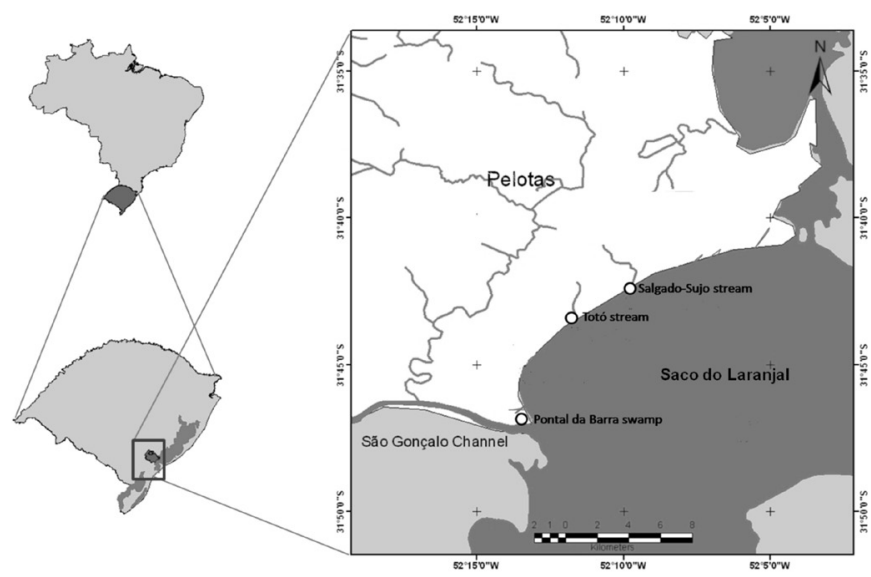

FiguRE 2. Distribution map of Dormitator maculatus in the Patos-Mirim lagoon system. Author: Hélio Neto.

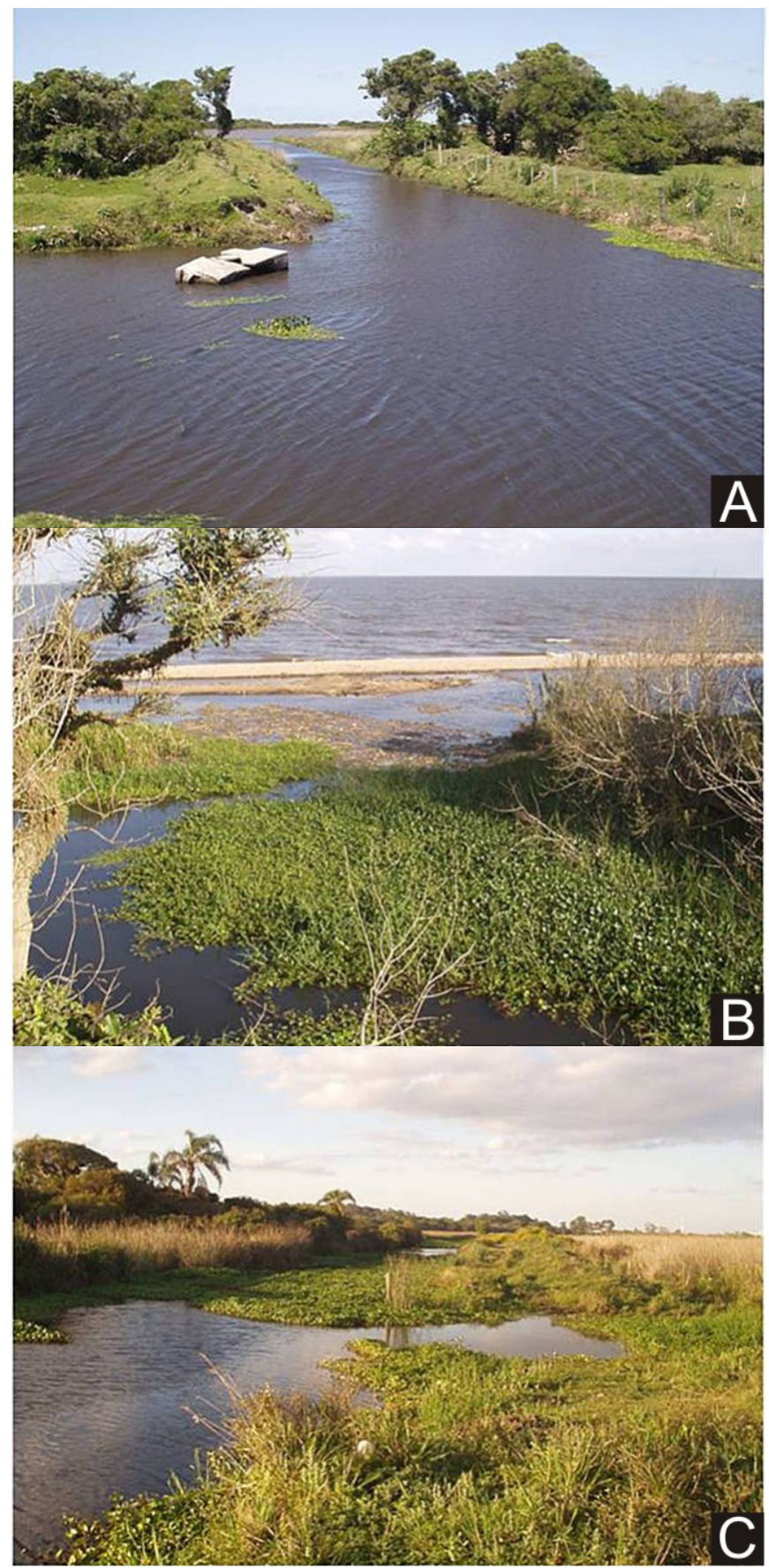

FIGURE 3. Sampling sites of Dormitator maculatus in the municipality of Pelotas, Patos-Mirim lagoon system, RS. (A) Sampling site changed by drainage works bathed in Pontal da Barra swamps; (B) Totó stream; (C) Salgado-Sujo stream. Photos: Matheus Volcan.
Although D. maculatus has a wide distribution (see Froese and Pauly 2010), the species occurs only in a limited range near the sea, one of the regions that is suffering the most from the impacts of human occupation, such as change and pollution of water bodies, deforestation and land divisions (Abilhoa and Duboc 2004). Due to the fact that this species was rarely collected in the state of Paraná and anthropic changes have been recorded in its habitat, $D$. maculatus was included in the red list of threatened fauna of the state of Paraná (Abilhoa and Duboc 2004). In Rio Grande do Sul, although the species was recorded in a protected area, the Parque Nacional da Lagoa do Peixe (Loebmann and Vieira 2005), there are few records their populations and several publications in the coastal plain of the Rio Grande do Sul, including those with long-term sampling, have not recorded the presence of this species (e.g. Tagliani 1994; Garcia and Vieira 2001; Garcia et al. 2006). In addition, the populations of the Patos-Mirim lagoon system recorded in the present study suffers the same threats that populations from the state of Paraná. Therefore, it is possible that D. maculatus might be considered a species threatened with extinction in the state of Rio Grande do Sul.

ACKNOWLEDGMENTS: We thank Bruno Klotzel for assistance in collection of specimens and James Tepper for their assistance in translating the manuscript. This paper was improved by the comments of one anonymous reviewer and by Dr. Daniel Loebmann.

\section{Literature Cited}

Abilhoa, V. and L.F. Duboc. 2004. Peixes - Água Doce; In Mikich, S.B. and R.S. Bérnils (ed.). Livro vermelho da fauna ameaçada no Estado do Paraná. Accessible at: http://www.pr.gov.br/iap. Captured on: 24 mar 2010.

Bertaco, A.V. 2009. Freshwater Fishes, Ilha de Santa Catarina, southern coastal drainage of the state of Santa Catarina, Brazil. Check List 5(4): 898-902.

Froese, R. and D. Pauly. 2010. FishBase. World Wide Web electronic publication. www.fishbase.org, version (01/2010). Captured on 24 mar 2010.

Garcia, A.M. and J.P. Vieira. 2001. 0 aumento da diversidade de peixes no estuário da lagoa dos Patos durante o episódio El nino 1997-1998. Atlântica 23: 133-152.

Garcia, A.M., M.A. Bemvenuti, J.P. Vieira, D.L.M. Marques, M.D.M. Burns, A. Moresco and M.V.L. Condini. 2006. Checklist comparison and dominance patterns of the fish fauna at Taim wetland, South Brazil Neotropical Ichthyology 4(2): 261-268.

Keith, P., P.Y.L. Bail and P. Planquette. 2000. Atlas des poissons d'eau douce de Guyane (tome 2, fascicule I). Paris: Publications scientifiques du Muséum national d'Histoire naturelle. 286 p.

Kullander, S.0. 2003. Family Gobiidae (Gobies); p. 657-665 In Reis, R.E, S.O. Kullander, and C.J. Ferraris (ed.). Check list of the freshwater fishes of South and Central America. Porto Alegre: EDIPUCRS.

Loebmann, D. and J.P. Vieira. 2005 Distribuição espacial das assembléias de peixes na Lagoa do Peixe, RS, Brasil. Revista Brasileira de Zoologia 22(3): 667-675

Nelson, J.S. 2006. Fishes of the World. $4^{\text {rd }}$ ed.. New York: John Wiley \& Sons. $622 \mathrm{p}$.

Winemiller, K.O. and B.J. Ponwith. 1998. Comparative ecology of eleotrid fishes in Central America coastal streams. Environmental Biology of Fishes 53: 373-384.

Queiroz, G.M.N., H.L. Spach, M.S. Morelos, L.O. Santos, and R.S. Junior. 2006. Caracterização da ictiofauna demersal de duas áreas do complexo estuarino de Paranaguá, Paraná, Brasil. Biociências 14(2): 112-124.

Tagliani, P.R.A. 1994. Ecologia da assembléia de peixes de três riachos da Planície Costeira do Rio Grande Sul. Atlântica 16: 55-68.

RECEIVED: May 2010

REVISED: July 2010

ACCEPTED: August 2010

Published OnLINE: October 2010

EDITORIAL RESPONSIBILITY: Daniel Loebmann 